\section{Assessment of Thai teachers' performance in facilitating inquiry based instruction in Science on Filipino students: Inputs to Project Teacher Exchange for ASEAN Children $(\mathrm{TEACH})$ program}

Montebon, Darryl Roy T.

Philippine Normal University, Philippines (montebon.drt@pnu.edu.ph)

Received: 4 September 2016

Available Online: 18 October 2016

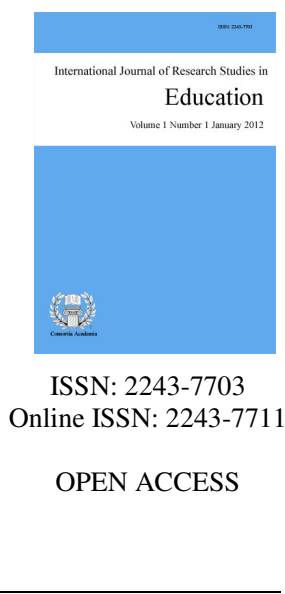

\title{
Abstract
}

The Project Teacher Exchange for ASEAN Children (TEACH) Program is an international training program that helps teachers from ASEAN countries in their English language proficiency and pedagogic skills. It allows its participants to explore the Filipino traditions through different culture immersion activities as described by Agustin, Montebon, and Rabina (2015). The present research reports the performance of the Thai teacher participants in facilitating inquiry based approach as their culminating activity for their pedagogic training in Project TEACH. The RTOP inquiry based evaluation tool developed by Isola and Wenning (2007) was accomplished by the Thai teacher participants, the students who participated in the demonstration program, and the critic teacher to determine the performance of Thai teacher participants in facilitating inquiry in the classroom. Open ended questions were also incorporated in the questionnaire and a focused group discussion was conducted to further investigate on the performance of the Thai teacher participants in their demonstration. It has been found out that the Thai teacher participants were successful in facilitating inquiry based approach through the $5 \mathrm{E}$ model of instruction. However, the Thai teacher participants struggled on asking questions of higher-order thinking. The said struggle has been related to their command of the English language. It is suggested that Project TEACH should provide more trainings to its Thai participants in the art of questioning. For future research, it is suggested that Thai teacher participants be visited and observed in their own classrooms in Thailand to determine if they have applied what they have learned in the Project TEACH program.

Keywords: Project TEACH; ASEAN integration; ASEAN 


\section{Assessment of Thai teachers' performance in facilitating inquiry based instruction in Science on Filipino students: Inputs to Project Teacher Exchange for ASEAN Children (TEACH) program}

\section{Introduction}

Inquiry based instruction is an effective pedagogy that has been proven by many researches in facilitating the teaching and learning process in the science classroom (Center for Inspired Teaching, 2008) The advantage of utilizing the inquiry based pedagogy mainly improves student achievement (White, Todd, \& Frederiksen, 2009; Marx, Blumenfeld, Krajcik, Fishman, Soloway, Geier, \& Tali Tal, 2004). In the Philippines, the inquiry based instruction is the prime pedagogy in the new K to 12 curriculum. It is believed that through inquiry based instruction, the $\mathrm{K}$ to 12 science curriculum can produce learners who are equipped with $21^{\text {st }}$ century skills and who are scientifically literate and socially responsive citizens.

Project Teacher Exchange for ASEAN Children (Project TEACH), as an international teacher training program, aims to share with its participants the best practices in Philippine schools that may help them when they go back to their sending country. In science education in the Philippines, it is the inquiry based instruction that is viewed to be the best practice in the country. Thus, the inquiry based instruction in teaching science has been the focus of the teacher training of Thai science teachers who participated in the Project TEACH program of the Philippine Normal University (PNU).

The framework of the Project TEACH program developed by Agustin, Montebon, and Rabina (2015), describes the three basic training components of the program, the English Language Proficiency (ELP) training, the Pedagogical Content Knowledge (PCK) and the Cultural Exposure. This research is focused on improving the Pedagogical Content Knowledge (PCK) trainings of the participants. The paper of Agustin et al. (2015) reports the evaluation of the Project TEACH program as whole. Upon evaluation, they have proposed that the framework of the program works in enhancing the ELP and PCK of the participants.

On the other hand, this research investigates in depth the performance of the Thai participants of Project TEACH as they facilitate the inquiry based instruction to their Filipino students during their demonstration time. The present research is important for the improvement of the Project TEACH program as well as it seeks to inform other teacher education institutions that also envision having a similar international teacher training programs.

\section{The Literature Review}

\subsection{The Inquiry Based Instruction and its Benefits in the Classroom}

The inquiry based mode of instruction according to the Center for Inspired Teaching (2008) is a pedagogy that allows students to explore the academic content by undergoing tasks that enables them to ask questions, plan how to solve the problem, investigate on the problem and formulate valid conclusions on the problem. Teachers who opt to use inquiry in the classroom assure their students of authentic experiences that will help them develop holistically. The inquiry based approach in science enriches the 'habits of the minds' of the students which prepares them to become lifelong learners.

Several researches have investigated on the effect of inquiry based instruction in the classroom. White, Shimoda, and Frederiksen (1999) found out that students exposed to the inquiry based approach performed better in class compared to the students exposed to traditional methods of teaching physics. Inquiry based method 
allowed high school students to take on authentic scientific investigations rather than focusing on facts and details. The students became responsible of their own learning and where able to create models to showcase what they have learned in the classroom.

The study of White, Shimoda, and Frederiksen (1999) also revealed that even the low performing students showed progress when they were exposed to the inquiry based approach of teaching in Physics. According to Kahle, Meece, and Scantelbury (2000), the inquiry based method instruction can narrow the gap between high performing and low performing students. The inquiry based curriculum also showed that students performed better in assessments when exposed to the curriculum (Marx et al., 2004). The low performing students in standards tests showed significant improvement when they taught using inquiry based approach. When inquiry based approach was applied to other subjects aside from Math and Science, it was found out that students learned more (Nystrand \& Gamoran, 1991). Such significant gain has been associated with students' exposure on more authentic questions in inquiry based teaching rather than the ones in traditional paper and pen tests.

The role of language and culture in facilitating inquiry based instruction is one of the interests of this study. Researches on the application of the inquiry based learning to teaching the English language also revealed significant improvement on students. The study of Amaral, Garrison, and Klentschy in 2002 revealed that students who are of Latino descents improved in their standardized tests when they were exposed to inquiry based method of instruction.

\subsection{Asking the right questions for effective inquiry}

The inquiry approach is centered in enabling students to discover knowledge that is essential and meaningful to them and utilize the said knowledge to accomplish personal goals (Aulls \& Shore, 2007). Thus, based on the said definition if inquiry approach it can be deduced that it can promote higher order thinking skills. But how does inquiry do that? The answer would lie on the questions being asked by the teacher or even the students. Delcourt and Mckinnon (2011) described that the foundation of inquiry instruction is the ability to ask questions. The inquiry based learning is founded on being curios and on asking questions. Inquiry can be equated with discovery, motivation, problem solving, critical thinking, and meaning making. Such characteristics of inquiry based learning require higher order thinking skills (Resnick, 1987).

High-order thinking according to Brookhart (2010) can be described with three characteristics which are transfer of knowledge, critical thinking, and problem solving. Teachers should prepare lessons that would go beyond simple recall and promote transfer of learning in different situations. In doing so, meaningful learning can be achieved. Another goal of teaching is also to promote critical thinking where students decide what knowledge is important and how does it apply to them. Students who are equipped with rational, reflective, and are able to make sound judgement can be described to be critical thinkers. The last characteristic of a person of high order thinking is the ability to manage his resources, utilize his knowledge, and determines the best way to solve a problem. Problem solving requires an interplay of high order thinking skills.

How do teachers ensure that what they are teaching promotes higher-order thinking skills? The instructional plan can answer the said question. Teachers' objective for a lesson should be of higher-order thinking. The questions asked to students should also promote higher-order thinking. Krathwol (2002) published the Revised Blooms Taxonomy which was derived from his previous work. The Revised Bloom's Taxonomy (RBT) shows the different classification of the educational objectives in the classroom. In the RBT, objectives that can be classified as of higher-order thinking goes beyond remembering and understanding. Lesson objectives that makes students to relate, transfer, evaluate, and create from the knowledge that they gained in their lessons are of higher-order thinking. To promote higher-order among students, Barak and Shakman (2008) explored how teachers foster higher-order thinking among students and the best way is to introduce the elements of constructivists pedagogy and combined with purposive steps to promote higher-order thinking. They suggested that higher-order thinking be a regular ingredient in science teaching within the current schooling system. 


\subsection{On Inquiry and Culture}

There are different characteristics that can describe an inquiry based approach but one of which is the evident questioning process between the teachers and students (Magee \& Meier, n.d.). Teachers using the inquiry based method utilize questions to instruct, verify, direct, and even challenge students. Therefore, the teachers' ability to ask questions is also a determinant of a successful implementation of the inquiry based method of teaching. While it is important for teachers to know how to facilitate classroom instruction using the inquiry based approach it is also essential to prepare how to go through when a teachers has to implement the instruction among students who are of different culture with the teacher. According to Derado (2015) the cultural dimension should be carefully considered for effective communication to take place. Therefore, cross-cultural competence among teachers and students should be developed.

According to Alfred and Byram (2002), they noted that an educational system that aims to produce globally competitive citizens must equip the learners with cross-cultural competence. Cross-cultural competence according to Derado (2015) is the ability to understand people of different culture to engage them in effective communication. It is noted that when the cross-cultural competence has been established between communicating parties, the goals whether personal of professional can be achieved. Therefore, the ability of the Thai teacher participants to speak in English is being enhanced in the Project TEACH program since the command of the language will determine the ability of the teachers to ask the right questions and facilitate classroom interaction successfully. The Project TEACH framework developed by Agustin et al. (2015) gives primer on the enhancement of English language skills of the participants particularly in facilitating classroom discussion. Different activities such as English language proficiency training and teaching strategies have been carefully designed for the participant to improve in their command of the English language and how they can facilitate classroom instruction in English. The participants are also given a chance to observed Philippine classrooms and practice what they have learned in the program through demonstration teachings.

Culture plays an important role and can affect facilitating classroom instruction through inquiry method. Phelan, Davidson, and Cao (1991) describes that culture should be coherent with the values and beliefs embodied in an inquiry based instruction and with that its participants. If not, it can yield to failure of "border crossing" whereby students can transfer from one worldview to another as they are in pursuit of knowledge. The success rate of "border crossing" is largely dependent on the ability of the teachers to prepare and help their students.

In the present paper, culture refers to the values and systems of a certain ethnic group that primarily describes how their school system works. Specifically, what is referred to here is Thai school culture and Filipino school culture. Since the Philippines is the country giving support to the Thailand teachers in Project TEACH, the Thai teacher participants were trained how to conduct inquiry based methods as to Philippine education context. Hence, the inquiry based method is deemed to be an important training for Thai teachers because the pedagogy can truly help improve the science education in the ASEAN region. Though both countries, Philippines and Thailand, dictate that science should be taught using the inquiry method, it is believed that the two countries can still learn from each other.

Buarapha, Singh, and Roadrangka (2006) studied physics classroom in a university and found out that the science classroom is still highly lecture dominated rather than students taking active roles in the class. In relation to this, the study of Soankwan (2007) that Thai students find science, Physics in this case, to be a difficult subject. With the said challenges faced by Thai science education system, it is desired in this study to help Thai teachers through Project TEACH to facilitate better inquiry based method of instruction.

\subsection{Research Purpose}

This research primarily is being undertaken to assess the performance of Thai teachers as they facilitate 
Assessment of Thai teachers' performance in facilitating inquiry based instruction in Science on Filipino students classroom instruction using the inquiry based pedagogy with the Filipino Students. The outcomes of the research will be utilized to improve the Project TEACH program. The following are the specific objectives that the present research aims to accomplish:

$>\quad$ Describe level of performance in facilitating inquiry based method of Thai teacher participants of Project TEACH program

$>\quad$ Describe the questioning techniques of Thai teacher participants as they facilitate inquiry based pedagogy among Filipino students

$>\quad$ Determine the challenges encountered by the Thai teacher participants as they facilitate inquiry based pedagogy among Filipino students

$>$ Suggest improvements for the Project TEACH program to further help the participants of the program

\section{Methodologies}

\subsection{Respondents}

Three groups of respondents were purposely selected to be the respondents of the present research. The primary group of respondents of this study include the seven (7) Thai teacher participants of the Project Teach program. They were all female and their age range is from 27 to 44 years old. Five of them have been teaching science for less than seven years while the other two has been a science teacher for about ten and twenty years. In Thailand, five participants are handling general science subjects while the other two are teaching Biology. Another respondent for the study are the fifteen (15) Filipino students, eight female and seven male, who participated in the demonstration program. They are all freshman students in the university whose age range vary from 16 to 17 years old. The last source of data in the present research is the evaluation coming from the critic teacher who facilitated the Thai teacher participants in their demonstration activity. He is also the coach of the Thai teacher in preparing for their demonstration. He was able to instruct the Thai teachers on how to go through with their classroom demonstration.

\subsection{Instruments and Data Sources}

There were three data sources used in the present research which are the answers of the student participants in the questionnaire for the demonstration period, the observations recorded by critic teacher, and the answers of the Thai teacher participants in the focused group discussions. The first part of the questionnaire that was utilized in the study is adapted from the Reformed Teaching Observation Protocol (RTOP) with 24 statements that the respondents can agree using the 5-point Likert scale. The inquiry-based self-assessment inventory developed by Isola and Wenning (2007) was modified to fit the specific group of respondents. The 24 statements can be grouped according to four areas that are being investigated in the scale. Table 1 below shows the description of each subscale, its location in the questionnaire, and the corresponding reliability coefficient.

\section{Table 1}

Specifications of the questionnaire

\begin{tabular}{llcc}
\multicolumn{1}{c}{ Categories } & \multicolumn{1}{c}{ Descriptions } & $\begin{array}{c}\text { Location in } \\
\text { the instrument }\end{array}$ & $\begin{array}{c}\text { Reliability } \\
\text { R-squared }\end{array}$ \\
\hline $\begin{array}{l}\text { Lesson Design and } \\
\text { Implementation } \\
\text { Content Knowledge }\end{array}$ & $\begin{array}{l}\text { Describes what the teacher intends to do in the } \\
\text { classroom } \\
\text { Covers the knowledge of the teachers on the } \\
\text { subject matter and what strategies were employed } \\
\text { to implement the learning plan }\end{array}$ & $1-7$ & 0.915 \\
Procedural Knowledge & $\begin{array}{l}\text { How the students were able to learn in the } \\
\text { classroom } \\
\text { The relationship between teacher and students and } \\
\text { how does one interact with the other }\end{array}$ & $13-17$ & 0.670 \\
Interactions & & $18-24$ & 0.946 \\
\hline
\end{tabular}


The overall reliability coefficient of the scale as to the equation for the best-fit line and the proportion of the variance accounted for by that line is high $\left(\mathrm{R}^{2}=0.954\right)$. To interpret the results from the Reformed Teaching Observation Protocol (RTOP), the total score was summed up and interpreted according to the following classroom vignette set by the http://serc.carleton.edu (2016).

\begin{tabular}{ll}
$\quad$ Score & \multicolumn{1}{c}{ Characteristic } \\
0 to 30 & Traditional/teacher-centered \\
31 to 45 & Transitional/teacher-guided \\
46 to 60 & Transitional/student-influenced \\
60 to above & Reformed/Student Centered
\end{tabular}

The part two of the questionnaire are open ended questions that deal with the questioning skills of the Thai teacher participants as they conducted their demonstration. Such questions investigate the level of questioning of the Thai teacher participants, the challenges that they have encountered on asking questions and how Project TEACH helped them address their varied concerns. The observations of the critic teacher were also considered to describe the performance of the Thai participants in their demonstration method. The observations include the actual implementation of the instructional plan as well as the analysis of the questions that were found in their instructional plans. The last data source for the present research is the output for the focused group discussions during the planning stage and the critic sessions after the class demonstration of the Thai teachers. Their responses on the questions of their critic teacher were noted to support the discussion in the present research.

\subsection{Research Design}

The present research utilized both the quantitative and the qualitative research design according to how it applies to the research question being asked in the study. To effectively describe how the Thai teacher participants performed in their demonstration teaching in the Project TEACH program, both quantitative and qualitative data are needed to be gathered and analyzed to comprehensively describe the performance of the Thai teacher participants of Project TEACH.

\subsection{Planning and Implementation}

The teaching demonstration highlights the experiences of the Thai teacher participants of the Project TEACH program. It serves as their culminating activity where they can showcase what they have learned in pedagogical sessions and English Language Proficiency trainings. For the part of the Project TEACH committee, the demonstration program is an important component to determine the success of the program. This research proceeds in three basic phases. The planning, the implementation, and the assessment. In the planning stage, the Thai teacher chose a topic in science and designed an instructional following the 5E model of inquiry based teaching. The instructional plan incorporates the learnings that the Thai teacher participants on their sessions on teaching and learning. Table 2 below shows the topics that were chosen by the Thai teacher participants and their objectives for the each lesson.

\section{Table 2}

Topics for demonstration

\begin{tabular}{ll}
\hline \multicolumn{1}{c}{ Topic } & \multicolumn{1}{c}{ Objective/s } \\
\hline Food Chain & Describe what is a food chain \\
& Create a food chain that can be found on a certain ecosystem \\
Parts of a Flower & Identify the parts of a flower \\
& Analyze the functions of each part of a flower \\
Plant Cells & Identify the parts of a flower \\
& Create a 3D model of a cell \\
Electrical appliances & Classify electrical appliances by energy conversion \\
& Determine the correct usage of appliances \\
\hline
\end{tabular}


Table 2 ... continues

\begin{tabular}{ll}
\hline Leaf anatomy & $\begin{array}{l}\text { Describe the structure of a leaf } \\
\text { Classify leaves according to certain categories } \\
\text { Starch in Food }\end{array}$ \\
& $\begin{array}{l}\text { Describe carbohydrate as a food content } \\
\text { Identify food that contains carbohydrates }\end{array}$ \\
Layers of the Earth & $\begin{array}{l}\text { Determine the different layers of the earths and their properties } \\
\text { Make model of the layers of the earth }\end{array}$ \\
\hline
\end{tabular}

As mentioned, the 5E model for inquiry based instruction was utilized in the creation and implementation of the instructional plan for the class demonstration. The 5E's are the engage, explore, explain, elaborate and evaluate. The activities have been prepared by the Thai teacher participants of and were presented to the critic teacher. The critic teacher then gave his comments on how to improve the plan and gave suggestions to be incorporated in the instructional plan. A specific instruction to include guide and linking questions in the instructional plan was also given. The Thai participants have worked on the revisions on the instructional plan and prepared the final version of the plan during the demonstration period time.

Table 3

Instructional Activities Implemented

\begin{tabular}{|c|c|c|c|c|c|}
\hline Topic & Engage & Explore & Explain & Elaborate & Evaluate \\
\hline Food Chain & Story Telling & $\begin{array}{l}\text { Picture analysis } \\
\text { of different } \\
\text { ecosystems }\end{array}$ & $\begin{array}{l}\text { Analysis of } \\
\text { student answers }\end{array}$ & $\begin{array}{l}\text { Creation of } \\
\text { original food } \\
\text { chain }\end{array}$ & Paper and Pen \\
\hline $\begin{array}{l}\text { Parts of a } \\
\text { Flower }\end{array}$ & $\begin{array}{l}\text { Singing of } \\
\text { Bulaklak } \\
\text { (flower) song }\end{array}$ & $\begin{array}{l}\text { Flower } \\
\text { dissection }\end{array}$ & Video & $\begin{array}{l}\text { Answering of } \\
\text { Worksheets }\end{array}$ & Paper and pen \\
\hline Plant Cells & Questioning & Cell City Video & $\begin{array}{l}\text { Cell City } \\
\text { Analogy }\end{array}$ & $\begin{array}{l}\text { Creation of 3D } \\
\text { cell Model }\end{array}$ & Paper and pen \\
\hline $\begin{array}{l}\text { Electrical } \\
\text { appliances }\end{array}$ & $\begin{array}{l}\text { Listing of } \\
\text { electrical } \\
\text { appliances at } \\
\text { home }\end{array}$ & $\begin{array}{l}\text { Picture and } \\
\text { analysis of } \\
\text { electrical } \\
\text { appliances }\end{array}$ & $\begin{array}{l}\text { Answering of } \\
\text { guide questions }\end{array}$ & $\begin{array}{l}\text { Video on } \\
\text { electrical } \\
\text { appliances use }\end{array}$ & Paper and pen \\
\hline Leaf anatomy & Video on leaves & $\begin{array}{l}\text { Group tasks on } \\
\text { leaf anatomy }\end{array}$ & Group reporting & $\begin{array}{l}\text { Venn Diagram } \\
\text { on the different } \\
\text { types of leaves }\end{array}$ & Paper and pen \\
\hline Starch in Food & $\begin{array}{l}\text { Identifying } \\
\text { Filipino Foods }\end{array}$ & Starch test & Group reporting & $\begin{array}{l}\text { Examples of } \\
\text { food with } \\
\text { carbohydrates }\end{array}$ & Paper and Pen \\
\hline $\begin{array}{l}\text { Layers of the } \\
\text { Earth }\end{array}$ & $\begin{array}{l}\text { Class } \\
\text { discussion on } \\
\text { the properties of } \\
\text { the Earth }\end{array}$ & $\begin{array}{l}\text { Boiled Egg and } \\
\text { Earth layer } \\
\text { analogy }\end{array}$ & $\begin{array}{l}\text { Answering of } \\
\text { guide questions }\end{array}$ & $\begin{array}{l}\text { Video on } \\
\text { earth's layers }\end{array}$ & Paper and Pen \\
\hline
\end{tabular}

During the demonstration period the critic teacher carefully observed the demonstration of the Thai practice teachers and noted the questions that were asked to students. How the students participated and interacted with the teacher were also noted to determine if the Thai teacher participants are encouraging students to ask questions also and determine how they can handle the said questions. The students who are participating in the discussion were instructed to also carefully observe the Thai teacher participants as they conduct their demonstration teaching. The students were told to list the questions that they find too hard to answer or they found vague and the questions that are too easy as well.

For the assessment part, the Thai teacher participants were asked to answer the questionnaire prepared by the researcher on their performance in their classroom demonstration. After all the demonstration was done, a focused group discussion was conducted to gather the experiences that the Thai teacher participants experienced. A separate questionnaire was given to each student participant to evaluate the performance of each Thai teacher participant. The content of the questionnaire is parallel to that answered by the Thai teacher participants. A 
Montebon, D. R. T.

similar questionnaire was also answered by the critic teacher.

\section{Results and Discussion}

The present research aims to primarily describe how the Thai teacher participants of Project TEACH performed in their demonstration period using the inquiry based method. This section aims to report the said performance and answer the other research questions asked.

\subsection{Demonstration Performance of the Thai Teacher Participants}

After accomplishing the questionnaires of all the Thai teacher participants, student participants in the demonstration period, and the critic teacher the scores have been analyzed using descriptive and inferential measures. The result of the said analysis is shown in Table 4 below.

\section{Table 4}

Anova Thai Teacher Performance in Facilitating Inquiry Based Instruction

\begin{tabular}{lccccc}
\hline & Sum of Squares & df & Mean Square & F & Sig. \\
\hline Between Groups & 357.69 & 2 & 178.844 & .444 & .648 \\
Within Groups & 8053.79 & 20 & 402.690 & & \\
Total & 8411.47 & 22 & & & \\
\hline Note $: * p=0.05$ & & & &
\end{tabular}

The total mean $(\mathrm{M}=62.3913, \mathrm{SD}=19.55)$ obtained in the questionnaire given on the performance of the Thai teacher participants of Project TEACH in their demonstration period using the inquiry based method falls on the highest classification of scores according to the RTOP interpretation of http://serc.carleton.edu (2016). The result means that the Thai teacher participants managed a classroom with the characteristics of an inquiry based teaching approach which is student centered. It shows that the class managed by the Thai teacher participants maximized student potential because of an open interaction between the teacher and the student participants. The instruction utilized by the Thai teachers characterizes that of an inquiry based teaching approach where students build on prior knowledge and utilized scientific means to represent concepts that were learned. The students were also allowed to create and manipulate models to investigate further on the concept being taught. The students were also allowed to discuss within the group how to solve a certain problem and present results in class. Students were actively engaged in a positive learning environment where they can explore science concepts in depth and can communicate openly with each other as facilitated by teachers who are generally patient with them.

Looking at the mean obtained for the different groups of participants, it can be observed that the students $(\mathrm{M}=65.267, \mathrm{SD}=23.861)$ gave a higher rating to the performance of the Thai teacher participants compared to the rating of the critic teacher $(M=56.00)$ and the Thai teacher participants themselves $(M=57.1429, S D=3.71612)$. However, the ANOVA test showed that such difference is not significant ( $p=0.648$, at $0.06 \mathrm{sig}$ ). It means that in general the observations of the different groups of respondents on the performance the Thai teacher participants in their demonstration class do not significantly differ from each other.

\subsection{Assessing Thai Teacher Participants' Questioning Skills}

The art of questioning is an important element in facilitating inquiry in a science classroom. Asking the right questions can elicit the right answers leading to a successful classroom interaction. This section presents the questioning techniques that Thai teacher participants utilized in their demonstration lessons. The Thai teacher participants were asked in the questionnaire two questions on their questioning processes. The first question asked to them was "How will you rate your questioning skill during your demonstration process?" There were six out of seven participants $(86 \%)$ who rated their performance to be 'moderate'. They were not able to explain their responses why they rated only moderate and not excellent. 
The student participants were also asked to rate the questioning skills of the Thai teacher participants as to poor, just right and excellent. All of them (100\%) rated their teachers' performance to be just right which means it agrees with the self-evaluation of the Thai teacher on questioning skill to be moderate only. The students explained that they rated it to be just right because the fluency of asking questions can still be improved. The students noticed that the Thai teacher participants because they are still thinking of the right words to be used in asking questions. However, though there is a language barrier among the students and the teachers they appreciate the effort exerted by their Teachers to make them understand the questions that they are asking.

For the critic teacher, the performance of the Thai teachers fall above average due to the improvements he has seen among the Thai teacher participants. The initial instructional plans of the Thai teacher participants do not include guide questions. However, during the demonstration period the questions that were found on the instructional plan of the Thai teachers were given. The critic teacher agrees with the students that though language has been a constant challenge during the entire demonstration period, the efforts exerted by the Thai teacher participants on asking the right questions is very notable.

The Thai teacher participants were also asked to classify the questions that they have asked as to high or low order thinking. The were 4 respondents (57\%) who said it they asked lower order thinking questions while 3 of them $(43 \%)$ said it was high order thinking questions. The Thai teacher participants who rated their questions to be higher order said that they have asked questions that require students to analyze, practice critical thinking, and engage students to deep thinking. On the other hand, the Thai teacher participants who rated their questions to be low order explained that their questions were few due to time constraints and their foundations on questioning is not in depth.

The students were also asked to classify some specific questions that they have heard during the discussion as to 'good' and 'needs to be improved'. A sample question that they have listed under good questions is "why are plants important?" and under needs to be improved is "Who is a cell?" There were few sample questions that were given by the students since they were busy participating in the demonstration activities. The critic teacher also noted the questions asked by the Thai teacher participants in their demonstration class. The questions that have been asked by the teachers come in varied forms. The questions asked by the teachers were classified according to Revised Bloom's cognitive level of questioning. Upon analysis there were 50 questions asked by all the Thai teacher participants. Figure 1 below shows the distribution of the questions according to Revised Bloom's cognitive level.

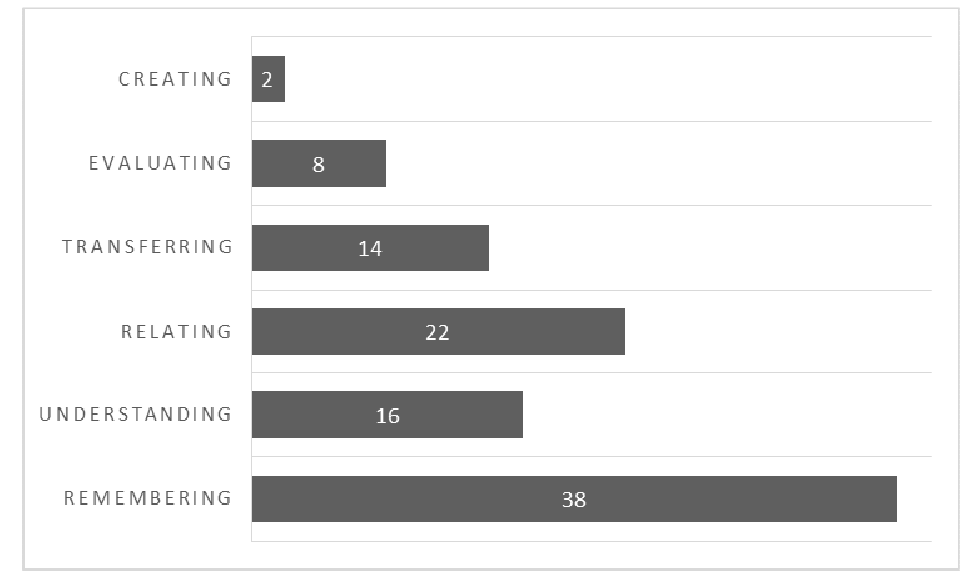

Figure 1. Classification of the questions asked by Thai teacher participants in percent $(\mathrm{N}=50)$

Based on the graph above it can be deduced that the Thai teacher participant mostly asked lower level questions which fall under remembering and understanding categories (54\%). Most of the questions asked by the Thai teacher's only allow students to identify phenomena and concepts. The said questions were identified to fall 
only in the remembering and understanding level of the Revised Bloom's Taxonomy. Sample questions that were asked in this category include "What are the layers of earth? What are cells? What are the parts of a plant?" However, there were questions asked that fall under higher order thinking skills too. A cumulative $46 \%$ comprise the total questions asked by the Thai teacher participants. Below are sample questions that were observed to be in the higher order thinking skills.

$>$ Relating: What type of leaf are you holding? Why do you say so?

$>$ Transferring: Based on our discussion, how would you classify the given appliances as to their energy conversion mechanism?

Evaluating: What would happen to the ecosystem if one of its food chain gets disrupted?

$>$ Creating: Can you make a model of the earth's layers using the materials given?

The observations of the critic teacher and the self-evaluation of the Thai teacher participants on their questioning ability agrees with each other that the Thai participants have been asking mostly low level questions but also gave higher order thinking questions. In inquiry, scaffolding of questions is needed to bridge students' ideas from simple to complex ones. Low level questions are needed before high level questions can be asked.

\subsection{Challenges on Facilitating Inquiry}

To determine the areas that Thai teachers need more help in facilitating inquiry is another aim of the present research. From the answers of the Thai teacher participants on the focused group discussion that was done after the demonstration several reasons have been pointed out. Language is the primary concern of the Thai practice teachers in their method of asking questions. Though they have written their questions well in their instructional plan they were challenged to ask it orally. One of the Thai teacher participants even asked "Who is a cell?" instead of asking "What is a cell?" Another Thai teacher respondent said that "I can't ask my questions well." These concerns are primarily anchored in their ability to utilize English as a medium of instruction. Though they are all in agreement in pointing out that they are struggling to ask questions in English they all agreed that they are thankful for the Project TEACH program in enhancing their language skills in English. They said that what they have learned in the program can really be applied when they go back to their classrooms in Thailand.

Another notable response from the Thai teachers is that even they find it hard to ask questions in English they were still able to relay what they mean to students because of the attitude of the students. Thai teachers have noticed how Thai learners differ from Filipino students in terms of class participation. They said that Filipino learners are very cooperative and polite towards them. Filipino students are very active in class and that they are not of asking questions to the teachers. The students' observations agreed with the concern of Thai teachers in Language. They said they find it hard to understand some of the words that the Thai teachers are saying because of the accent and the diction as they pronounce the words. The accent and diction hinder the clarity of the statements given and it affects the way they ask questions. However, the students also observed that if the Thai teachers sense that they can't understand what they are saying or asking, they were patient in rephrasing their statements and give examples and analogies so they can relate their thoughts to the students. The said attitude of the Thai teachers made them understand what they are teaching during the demonstration process.

The observations of the critic teacher agree with the main challenge encountered by the Thai teacher participants which is the Language barrier. But even with the said challenge, the critic teacher has observed that the Thai teacher participants were very eager to succeed in their classroom demonstration. Some of the questioning techniques that were observed by the critic teacher were scaffolding, probing, and clarifying. The critic teacher also observed that the Thai teacher participants provided hints to questions by paraphrasing the question and not just giving the first letter of the answer. It is understandable that the facilitating inquiry in a different set of students in terms culture is really challenging. What is notable to the Thai teacher participants of the Project TEACH program is their attitude to implement a lesson through inquiry approach using English instruction. They were able to provide activities that will lead students to the right answers in their questions. 


\section{Conclusions}

The Project TEACH program has allowed Thai teacher participants to facilitate a science classroom using the inquiry based approach effectively. The Thai teacher participants themselves, the students who participated in the demonstration, and the critic teacher all agreed that the science demonstration had the characteristics of an inquiry based approach. The Thai teacher participants were able to conduct their demonstration using inquiry based method successfully by providing activities that students can explore the science concepts being taught. However, the Thai teacher participants need more help in asking questions that are of higher order thinking skills. Based on the results, the questions that were mostly asked by the Thai teacher participants are of lower level thinking only. The students and the critic teacher also noted that the Thai teacher participants find it challenging to ask questions in English. However, Thai teacher participants were able to rephrase their questions and give hints on what they mean when they notice that students could not understand what they are trying to ask.

\subsection{Inputs to Project TEACH}

Based on the findings of the present research it can be said that the Project TEACH has been effective in providing teachers with pedagogical trainings. The inquiry based approach as used in science instructions has been utilized by the Thai teacher participants in their classroom effectively. It is suggested that such practice of training foreign teachers with pedagogies that they can apply to their home country be continued. The results of the research showed that what Thai teacher participants find hard to do in the inquiry based teaching is more of asking questions rather than the procedures and preparing activities. It is suggested that for Thai teacher participants in science should have ELP trainings on the art of questioning due to its usability in facilitating inquiry based instruction. It would be interesting to know if it would be different if they are asking questions in their own language. Will they have the same performance in asking questions? How would Thai students respond to their teacher asking them science questions in English? How is the inquiry process done in a Thai classroom? It can also be a good study to determine the extent of applying what they have learned in Project TEACH in their own classrooms in Thailand. Thus, a follow up visit and observation in the actual classroom of the Thai teacher participants be made.

Acknowledgements: This research has been accomplished under the Project TEACH 2016 program with Prof. Ma. Lourdes Santiago Agustin as the overall director. This paper is a product of one the evaluations done on Project TEACH program 2016.

\section{References}

Agustin, M. L., Montebon, D. R., \&Rabina, M. (2015). An Assessment of Project Teacher Exchange for ASEAN Teachers (TEACH) Program: Towards the development of a model for an international teacher training. Unpublished Manuscript.

Alfred, G., \& Byram, M. (2002). Becoming an intercultural mediator: A longitudinal study of residence abroad. Journal of Multilingual and Multicultural Development, 23(5), 339-352. http://dx.doi.org/10.1080/01434630208666473

Amaral, O., Garrison, L., \& Klentschy, M., (2002). Helping English learners increase achievement through inquiry-based science instruction. Bilingual Research Journal, 26(2), 225-234. http://dx.doi.org/10.1080/15235882.2002.10668709

Aulls, M. W., \& Shore, B. M. (2007). Inquiry in education: the conceptual foundations for research as a curricular imperative. New York: Erlbaum.

Barak, M., \& Shakhman, L. (2008). Fostering higher-order thinking in science class: teachers' reflections. Teachers and Teaching, 14(3), 191-208. http://dx.doi.org/10.1080/13540600802006079

Brookhart, S. M. (2010). How to assess higher-order thinking skills in your classroom. Retrieved from 
Montebon, D. R. T.

http://www.ascd.org/publications/books/109111/chapters/Introduction.aspx

Buarapha, K., Singh, P., \& Roadrangka, V. (2006). Teaching, learning and conceptual development of force and motion in third-year preservice physics teachers. The Journal of Behavioral Science, 1(1), 62-66

Center for Inspired Teaching. (2008). Inspired issue brief: Inquiry-based teaching. Retrieved from http://www.inspiredteaching.org

Delcourt, M., \& Mckinnon, J. (2011). Tools for Inquiry: Improving questioning in the classroom. Learning Landsacpes, 4(2), 145-159.

Derado, S. R. (2015). Fostering cross-cultural communicative competence in business English classes through literary short stories. ESP Today Journal of English for specific purposes at tertiary level, 3(1), 99-119.

Isola, D., \& Wenning, C. (2007). Inquiry-based (aka Reformed) teaching self-assessment inventory. Retrieved from http://www.modeling.asu.edu/MSN/RTOP_SelfAssessment07.doc

Kahle, J. B., Meece, J., \&Scantlebury, K. (2000). Urban African-American middle school science students: Does standards-based teaching make a difference? Journal of Research in Science Teaching, 37(9), 1019-1041. http://dx.doi.org/10.1002/1098-2736(200011)37:9<1019::AID-TEA9>3.0.CO;2-J

Magee, D., \& Meier, A. (n.d.). Science education and culture: Inquiry based learning. The College of New Jersey \& University of Iowa, USA.

Marx, R., Blumenfeld, P., Krajcik, J., Fishman, B., Soloway, A., Geier, A., \& Tali Tal, R. (2004). Inquiry-based science in the middle grades: Assessment of learning in urban systemic reform. Journal of Research in Science Teaching, 4l(10), 1063-1080. http://dx.doi.org/10.1002/tea.20039

Nystrand, M., \& Gamoran, A. (1991). Instructional discourse, student engagement, and literature achievement. Research in the Teaching of English, 25, 261-290.

PhysPort Implementation Guide: Reformed Teaching Observation Protocol (RTOP). (2016). Retrieved from http://www.PhysPort.org

Resnick, L. B. (1987). Education and learning to think. Washington, DC: National Academy Press.

Soankwan, C., Emarat, N., Arayathanikul, K., \& Chitaree, R. (2007). Physics education in Thailand. International Newsletter on Physics Education, 6-8.

White, B., Shimoda, T., \& Frederiksen, J. (1999). Enabling students to construct theories of collaborative inquiry and reflective learning: Computer support for metacognitive development. International Journal of Artificial Intelligence in Education, 10, 151-182. 